\title{
Drinking water: a major source of lead exposure in Karachi, Pakistan
}

N. Ul-Haq, ${ }^{7}$ M.A. Arain, ${ }^{2}$ N. Badar, ${ }^{2}$ M. Rasheed ${ }^{3}$ and Z. Haque ${ }^{2}$

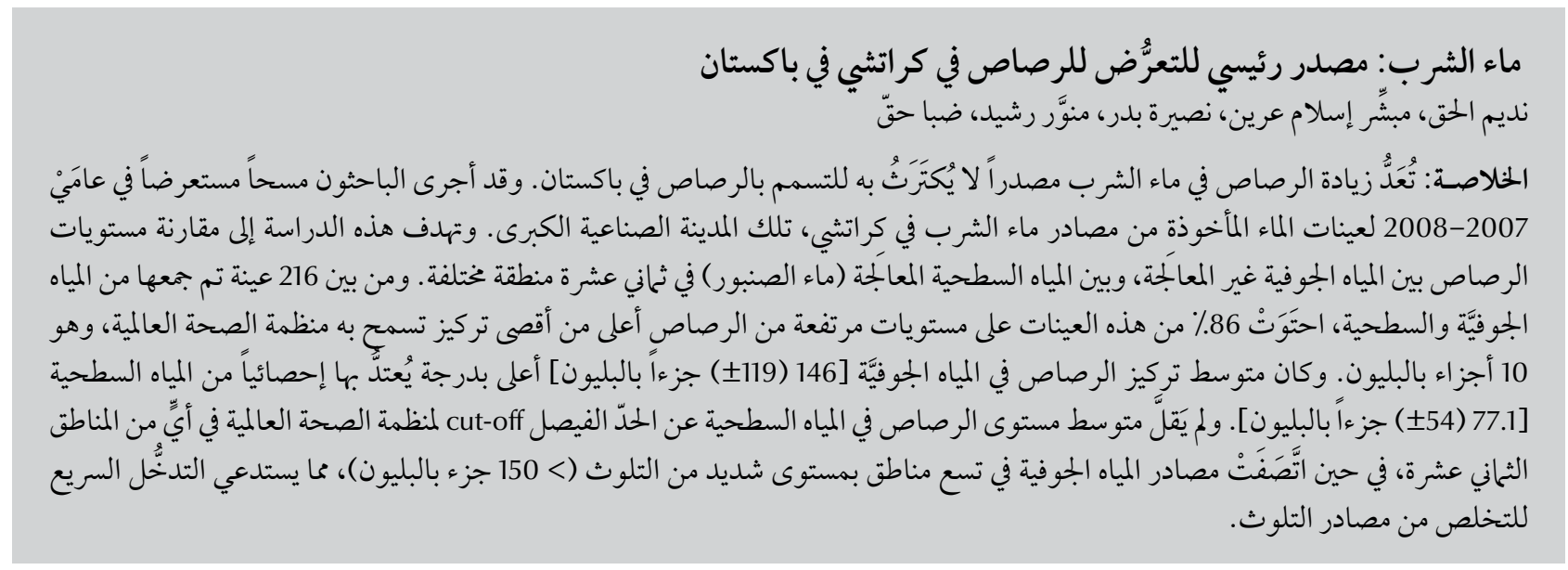

ABSTRACT Excess lead in drinking water is a neglected source of lead toxicity in Pakistan. A cross-sectional survey in 2007/08 was made of water samples from drinking water sources in Karachi, a large industrial city. This study aimed to compare lead levels between untreated ground water and treated surface (tap) water in 18 different districts. Of 216 ground and surface water samples collected, 86\% had lead levels higher than the World Health Organization maximum acceptable concentration of 10 ppb. Mean lead concentration in ground water [146 (SD 119) ppb] was significantly higher than in surface water [77.1 (SD 54) ppb]. None of the 18 districts had a mean lead level of ground or surface water below the WHO cut-off and ground water sources in 9 districts had a severe level of contamination (> $150 \mathrm{ppb}$ ). Urgent action is needed to eliminate sources of contamination.

\section{Eau de boisson : une source majeure d'exposition au plomb à Karachi (Pakistan)}

RÉSUMÉ Au Pakistan, une quantité excessive de plomb dans l'eau de boisson représente une source ignorée d'intoxication par ce métal. Une enquête transversale réalisée en 2007 et 2008 a analysé des échantillons d'eau provenant de sources d'eau de boisson à Karachi, une grande ville industrielle. Cette étude visait à comparer les taux de plomb des eaux souterraines non traitées et des eaux de surface traitées (robinet) dans 18 districts. Elle a révélé que 86 \% des 216 échantillons d'eaux souterraines et de surface présentaient des taux de plomb supérieurs à $10 \mathrm{ppb}$, la concentration maximale acceptable selon l'Organisation mondiale de la Santé. La concentration moyenne de plomb dans les eaux souterraines [146 ppb (E.T. 119)] était significativement supérieure à celle des eaux de surface [77,1 ppb (E.T. 54)]. Dans aucun des 18 districts, le taux de plomb moyen pour les eaux souterraines ou de surface n'était inférieur au plafond de l'OMS. De plus, les sources d'eau souterraines de neuf districts présentaient un niveau de contamination très élevé (> 150 ppb). Une action urgente est requise pour supprimer les sources de contamination. 


\section{Introduction}

Water contamination is as a major source of health problems, particularly in the developing world. Lead contamination of drinking water supplies can have deleterious effects on multiple organ systems, including the nervous, haematopoietic, renal, endocrine and reproductive systems, especially in children [1-5]. The principal routes of exposure and absorption of lead are through ingestion and inhalation, and around $35 \%$ to $50 \%$ of lead in drinking water gets absorbed in adults, a figure that can rise to $60 \%$ in children [6].

Excess lead in drinking water is a threat for population health not only in developing countries but also in the developed world. However, it is considered an overlooked source of lead toxicity [7]. In Pakistan few studies have been carried out on the health effects of lead through multiple lead exposure sources [8], although excessively high lead levels in drinking water have been reported in some areas of Karachi $[4,9]$. One community-based study hypothesized that high lead levels in blood may be a factor associated with hypertension in the Pakistani population [10]. A systematic review in Pakistan reported that more than half of children had higher than normal blood lead levels. Several factors are responsible for high lead exposure in Pakistani children, including paint, cosmetics, drugs, industrial waste and drinking water; however atmospheric lead exposure has been reduced since the introduction of lead-free petroleum fuel in 2001 [11].

The drinking water supply in Karachi city is mostly obtained through the municipal tapwater and local ground water [12], yet data are scarce regarding lead contaminated sources and their concentration in the different regions of Karachi. The aim of this study was to determine the concentration of lead in the tapwater and ground water of different areas of Karachi in order to prioritize actions on contaminated water sources in these areas.

\section{Methods}

This community-based water quality assessment survey was conducted from June 2007 to February 2008 in Karachi by the Department of Biochemistry at the Basic Medical Sciences Institute, Jinnah Postgraduate Medical Centre, Karachi.

\section{Sampling}

We examined 216 water samples obtained from drinking water sources in residential areas. Samples were collected from the end-users' drinking water sources, including houses and apartments of various locations in 18 districts of the city [13].

From each district 6 ground water and 6 surface water samples were collected. Surface water was defined as tapwater coming from rivers, dams and other storage sources, supplied to the city after filtration. Ground water samples were from those sources where individual houses, industries or small communities obtained their own water through boring into the land. This water usually does not go through any filtration plant and is used by the households in the original form by considering it pure underground water.

\section{Data collection}

Samples were collected in $1 \mathrm{~L}$ polyethylene, acid-resistant bottles that had been washed, rinsed with deionized water and dried. Bottles were completely filled with water samples and $5 \mathrm{~mL}$ of concentrated $\mathrm{HNO}_{3}$ was added as preservative to adjust the $\mathrm{pH}$ to $<2.0$ to maintain heavy metal concentrations. Samples were marked with unique numbers with dates. Samples were collected manually by the authors and trained data collectors. Water samples were obtained from tap after 1 minute running of water out of the tap to prevent falsely excessive heavy metal concentration.

An atomic absorption spectrophotometer (AAnalyst 700, Perkin Elmer), at recommended wavelengths for metal ions, was used as per standard procedure published by the American Public Health Association for the examination of water and wastewater method. Further details are explained in another published paper [14].

On site measurement of $\mathrm{pH}$ was conducted using a digital $\mathrm{pH}$ meter (Hanna, HI 9024) with a temperature probe. The meters were calibrated at 2 points against standard buffer solutions of $\mathrm{pH} 7$ and 9 prior to each measurement.

Conductivity and total dissolved solids of the spot samples was measured with microprocessor portable conductivity/TDS meter (Hanna H 1-9835). The manufacturer's calibration procedure was followed to obtain the guaranteed precision and accuracy. The conductivity meters were calibrated before each measurement against a standard solution of potassium chloride of known conductivity.

\section{Statistical analysis}

The data were entered and analysed using SPSS, version 15. Chi-squared and Student $t$-test were applied for categorical and continuous variables respectively for individual district readings of lead concentration. In addition multiple district comparisons of ground water was done using Kruskall-Wallis test at the $95 \%$ level of significance. A median ranking was made for each district on the basis of ground water lead levels.

\section{Results}

A total of 216 ground $(n=108)$ and surface $(n=108)$ water samples were collected from 18 districts of Karachi (6 from each drinking water source).

A great majority of the water samples $(88 \%, 190 / 216)$ had lead levels higher than the maximum acceptable concentration in drinking water established by WHO (10 parts per billion (ppb)] [15]. While 90\% (97/108) of 
the groundwater samples had lead levels about the WHO cut-off compared with $86 \%$ (93/108) of surface water samples, the difference was not significant $\left(\chi^{2}=\right.$ $0.9 ; P=0.2$ ).

Overall, the mean lead quantity in ground water [146 (SD 119) ppb] was significantly higher than in surface water $[77($ SD 54) ppb] $(P<0.001)$. When the concentrations of lead were compared in each of the 18 districts, 7 districts had significantly higher mean lead levels in ground water as compared to surface water of the same district (Table 1). No districts had a mean lead level of ground or surface water below the WHO recommended levels of 10 ppb.

We classifies the districts into 3 zones of mild, moderate and severe lead contamination according to their mean lead levels in drinking water: < $50 \mathrm{ppb}$ (the WHO cut-off until 1993) [15], from $50-150 \mathrm{ppb}$ and $>150$ ppb respectively. Only ground water sources were compared in Table 2 and significant differences were found between lead levels in the drinking water of 18 districts $\left(\chi^{2}=65.3, P<0.001\right)$. The median ranking ground water sources of all districts revealed that Bin Qasim had the lowest lead concentration in drinking water, with median levels of 8 ppb and at the other extreme Jamsheed, Badia, Kimari, Liyari and Orangi ranked highest with median lead levels above $200 \mathrm{ppb}$ (Table 2).

The $\mathrm{pH}$ in groundwater samples was in the acceptable range and no significant difference was found between the $\mathrm{pH}$ readings of ground and surface water samples [mean 7.3 (SD 0.4) versus mean 7.4 $(\mathrm{SD} \mathrm{0.4)})(P=0.8)$.

Mean total dissolved solids in ground water samples was 1084 (SD 913) $\mathrm{mg} / \mathrm{dL}$, which was significantly higher than in surface water samples $[291(\mathrm{SD} 37) \mathrm{mg} / \mathrm{dL}](P<0.001)$. Kamari, Orangi, Lyari, Gulshan, Baldia, Site, Jamshed and Malir towns had total dissolved solids level $>1000 \mathrm{ppm}$ and in other towns they were between 500 and $1000 \mathrm{ppm}$.

\section{Discussion}

The process of rapid industrialization and urbanization has created problems of water pollution in megacities such as Karachi. Despite generally improved sanitation, a lack of rational water management practices has led to a deterioration, both chemically and biologically, in the quality of ground and surface water sources [16]. The results of this study revealed that most of the sources of tap (surface) water and ground water were contaminated with unacceptably high levels of lead. The situation was worse in ground water which is becoming the most dangerous source of lead ingestion in the city.

Several studies have established a positive association of high blood lead

\begin{tabular}{|c|c|c|c|c|}
\hline \multirow[t]{2}{*}{ District } & $\begin{array}{l}\text { Lead levels in } \\
\text { surface water (ppb) }\end{array}$ & $\begin{array}{l}\text { Lead levels in } \\
\text { ground water (ppb) }\end{array}$ & $t$-value & $P$-value \\
\hline & Mean (SD) & Mean (SD) & & \\
\hline Bin Qasim & $13(15)$ & $14(18)$ & -0.07 & 0.9 \\
\hline Gidap & $16(19)$ & $28(27)$ & -0.1 & 0.3 \\
\hline Gulshan & $26(14)$ & $33(18)$ & -0.67 & 0.5 \\
\hline North Nazimabad & $23(43)$ & $35(41)$ & -0.47 & 0.6 \\
\hline Shah Faisal & $20(15)$ & $65(30)$ & -3.25 & 0.01 \\
\hline New Karachi & 95 (19) & $93(30)$ & 0.12 & 0.9 \\
\hline Gulberg & $98(39)$ & $100(92)$ & -2.5 & 0.9 \\
\hline Sadar & $75(21)$ & $135(59)$ & -2.4 & 0.04 \\
\hline Site & $110(55)$ & $140(44)$ & -0.4 & 0.6 \\
\hline Landhi & $100(76)$ & $160(74)$ & -1.4 & 0.2 \\
\hline Malir & $135(60)$ & $168(79)$ & -0.81 & 0.43 \\
\hline Korangi & 105 (49) & $185(39)$ & -3.1 & 0.01 \\
\hline Liaqatabad & $72(34)$ & $188(174)$ & -1.6 & 0.1 \\
\hline Jamsheed & $130(58)$ & 207 (105) & -1.5 & 0.1 \\
\hline Baldia & $75(16)$ & $207(108)$ & -2.9 & 0.02 \\
\hline Kimari & $120(51)$ & $270(1370$ & -2.5 & 0.03 \\
\hline Liyari & $92(26)$ & $270(47)$ & -0.82 & $<0.001$ \\
\hline Orangi & $85(27)$ & $320(174)$ & -3.2 & 0.02 \\
\hline
\end{tabular}

ppb = parts per billion; $S D=$ standard deviation . 


\begin{tabular}{|c|c|c|}
\hline \multicolumn{3}{|c|}{$\begin{array}{l}\text { Table } 2 \text { Kruskall-Wallis test for differences in lead levels of untreated ground } \\
\text { water drinking water supplies in } 18 \text { districts of Karachi grouped by level of } \\
\text { contamination ( } n=6 \text { samples in each district) }\end{array}$} \\
\hline Level of contamination/District & Median lead levels & Median rank \\
\hline & ppb & \\
\hline \multicolumn{3}{|l|}{ Mild (mean lead < $50 \mathrm{ppb}$ ) } \\
\hline Bin Qasim & 8 & 10.0 \\
\hline Gidap & 20 & 17.8 \\
\hline North Nazimabad & 20 & 19.5 \\
\hline Gulshan & 25 & 21.4 \\
\hline \multicolumn{3}{|l|}{ Moderate (mean lead 50-150 ppb) } \\
\hline Shah Faisal & 65 & 34.6 \\
\hline Gulberg & 70 & 44.3 \\
\hline New Karachi & 110 & 45.5 \\
\hline Sadar & 115 & 58.4 \\
\hline Site & 155 & 61.6 \\
\hline \multicolumn{3}{|l|}{ Severe $($ mean lead > $150 \mathrm{ppb})$} \\
\hline Liaqatabad & 150 & 61.8 \\
\hline Landhi & 200 & 63.9 \\
\hline Malir & 200 & 64.5 \\
\hline Korangi & 195 & 70.3 \\
\hline Jamsheed & 200 & 72.0 \\
\hline Baldia & 185 & 74.6 \\
\hline Kimari & 325 & 83.3 \\
\hline Orangi & 365 & 87.2 \\
\hline Liyari & 285 & 89.7 \\
\hline
\end{tabular}

levels with consumption of lead contaminated drinking water $[17,18]$. The health hazards from consuming such contaminated water are obvious [19]. Signs of chronic lead toxicity, including tiredness, sleeplessness, irritability, headaches, joint pains and gastrointestinal symptoms, may appear in adults at blood lead levels of 50-80 $\mu \mathrm{g} / \mathrm{dL}$. After 1-2 years of exposure, muscle weakness, gastrointestinal symptoms, disturbances in mood and symptoms of peripheral neuropathy were observed in occupationally exposed populations at blood lead levels of $40-60 \mu \mathrm{g} / \mathrm{dL}$. Renal disease has long been associated with lead poisoning; however, chronic nephropathy in adults and children has not been detected below blood lead levels of $40 \mu \mathrm{g} / \mathrm{dL}$.

In our study $86 \%$ of water samples had lead levels above the levels recommended by WHO, i.e. $10 \mathrm{ppb}$ [15]. Our results are consistent with the results of other water assessment studies in Pakistan [9]. On the other hand, one study from a developed country reported that only $3.7 \%$ of water samples from household drinking water were above the WHO recommended lead levels. In our study we also calculated mean lead levels in each district and found no district with a mean lead level of drinking water below the WHO recommended levels. According to our classification, although ground water sources in 9 districts were in the category of severe lead contamination.

In both water sources, our results of lead concentration were compatible with the results of Jaleel et al. in different districts of Karachi [9]. Lead is used in the production of lead acid batteries, solder, alloys, cable sheathing pigments, rust inhibitors, glazes and plastic stabilizers. Most of these industrial wastes are dumped into the rivers and soil without treatment. This is probably the major source of the high rates of lead contamination of drinking water in Karachi. Leaching from lead supply pipes is also a well known source of lead in tapwater [20] and corrosion of water and sewage pipelines, which may lead to release of heavy metals into drinking water, is a common occurrence, particularly in the older areas of Karachi.

In our study water $\mathrm{pH}$ was measured as lower $\mathrm{pH}$ can enhance corrosion of waterpipes [21,22]. However, we found all water samples from both surface and groundwater within the WHO recommended $\mathrm{pH}$ range of 6.5-9.5 [21] in all districts of Karachi. Although no healthbased guidelines are proposed for $\mathrm{pH}$, eye irritation and other skin disorders are associated with $\mathrm{pH}$ values $>11$.

Total dissolved solids may also lead to increased corrosion of water pipes. On the other hand few studies have shown that high total dissolved solids in water may have a protective effect on cardiovascular disease [23]. Total dissolved solids $<500 \mathrm{ppm}$ are considered as normal, although levels up to 1000 ppm may be acceptable concentrations [24]. In present study the mean concentration of total dissolved solids of tap water was below the $500 \mathrm{ppm}$ level [291 (SD 37) mg/dL], but the mean surface water concentration was higher than the WHO cut-off [1084 (SD 913) $\mathrm{mg} / \mathrm{dL}$.

Prospective studies with large sample sizes can determine the health effects of high lead contamination in the drinking water of Karachi. Children are at particularly high risk from lead contaminated water, and the long-term health problems need to be documented as most of the existing studies in Pakistan have been conducted on small samples [11]. Appropriate interventions are required to minimize lead levels in water. In addition there is a need to investigate the reasons for extreme differences in 
lead levels among different districts of the city so that the further sources of contamination can be eliminated.

\section{Conclusions}

Lead levels are extremely high in several drinking water sources in the industrial city of Karachi. This is particularly alarming in ground water sources, almost all of which had higher lead concentrations that the WHO acceptable limit of $10 \mathrm{ppb}$. Underground drinking water can be a source of heavy metal toxicity and needs thorough testing for unseen toxic substances such as lead. Mean lead quantity was $>150 \mathrm{ppb}$ in the ground water sources in half of the districts of Karachi. There is a need for further investigation of sources of lead in drinking water supplies in the city and for detailed inspection of water samples to be carried out in every area. In the worse affected districts there may be a need for cessation of some of the water sources to prevent the adverse consequences of lead toxicity in the public.

\section{Acknowledgements}

We acknowledge the support of Professor Zahida-T-Maqsood, Department of Chemistry, University of Karachi, for providing laboratory test facilities for the water samples.

We also acknowledge the academic support of Professor Khemomal A. Karara, Head of the Department of Biochemistry, Basic Medical Sciences Institute, Jinnah Postgraduate Medical Centre, Karachi, Pakistan.

\section{References}

1. Guidotti TL et al. Elevated lead in drinking water in Washington DC, 2003-2004. The public health response. Environmental Health Perspectives, 2007, 115:695-701.

2. Morales LS, Gutierrez P, Escarce JJ. Demographic and socioeconomic factors associated with blood lead levels among Mexican-American children and adolescents in the United States. Public Health Reports, 2005, 120:448-454.

3. Bryant SD. Lead-contaminated drinking water in the public schools of Philadelphia. Journal of Toxicology. Clinical Toxicology, 2004, 42:287-294.

4. Rahbar MH et al. Factors associated with elevated blood lead concentration in children in Karachi, Pakistan. Bulletin of the World Health Organization, 2002, 80:769-775.

5. Hu $\mathrm{H}$ et al. The epidemiology of lead toxicity in adults: Measuring dose and consideration of other methdologic issues. Environmental Health Perspectives, 2006, 115:455-462.

6. The nature and extent of lead poisoning in children in the United States: a report to Congress. Atlanta, Georgia, Agency for Toxic Substances and Disease Registry, 1988.

7. Renner R. Exposure on tap: drinking water as an overlooked source of lead. Environmental Health Perspectives, 2010, 118:a68-a72.

8. Rahman A, Hakeem A. Blood lead levels during pregnancy and pregnancy outcome in Karachi women. Journal of the Pakistan Medical Association, 2003, 53:529-533.

9. Jaleel MA, Noreen R, Baseer A. Concentration of heavy metals in drinking water of different localities in district east Karachi. Journal of Ayub Medical College, Abbottabad, 2001, 13:12-15.

10. Rahman $\mathrm{S}$ et al. Non-occupational lead exposure and hypertension in Pakistani adults. Journal of Zhejiang University. Science B, 2006, 7:732-737.

11. Kadir MM et al. Status of children's blood lead levels in Pakistan: implications for research and policy. Public Health, 2008, 122:708-715.

12. Naqvi SS. How safe is the water we drink? Dawn: the Review, 2006, 36:4-7 (http://archives.dawn.com/weekly/review/ archive/061102/review1.htm, accessed 4 August 2011).

13. Karachi strategic development plan 2020. Master plan group of offices. Karachi, Pakistan, City District Government of Karachi, 2007.
14. Nadeem-ul-Haq. Arain MA, Haque Z, Badar N, Mughal N. Drinking water contamination by chromium and lead in industrial lands of Karachi. Journal of the Pakistan Medical Association, 2009, 59:270-274.

15. Volume 1: Recommendations. In : Guidelines for drinking water quality, 2nd ed. Geneva, World Health Organisation, 1993.

16. Panday S. Water pollution and health. Kathmandu University Medical Journal, 2006, 4:128-134.

17. Sherlock JC, Quinn MJ. Relationship between blood lead concentration and dietary lead intake in infants: the Glasgow Duplicate Diet Study 1979-1980. Food Additives and Contaminants, 1986, 3:167-176.

18. Hazhorabri et al. Elevated blood lead levels among children living in a fishing community, Karachi, Pakistan. Archives of Environmental Health, 2004, 59:37-41.

19. Rehman A, Gazdar MN, Farooqi A. Future groundwater resources at risk. Poster papers of the international conference, Helsinki, Finland, 13-16 June 1994. Helsinki, Painatuskeskus, 1994.

20. Schck MR, Hyland RN, Welch MM. Occurrence of contaminant accumulation in lead pipe scales from domestic drinking-water distribution systems. Environmental Science and Technology, 2008, 42:4285-4291.

21. Fawell JK. $p H$ in drinking-water. Revised background document for development of WHO guidelines for drinking-water quality. Geneva, World Health Organization, 2007 (WHO/SDE/ WSH/07.01/1).

22. Webber JS, Covey JR, King MV. Asbestos in drinking water supplied through grossly deteriorated A-C pipe. Journal of the American Water Works Association, 1989, 81:80-85.

23. Shakirullah M, Ahmad I, Mehmood K. Physicochemical study of drinking water from Dir districts. Journal of the Chemical Society of Pakistan, 2005, 27(4):374-387.

24. Fawell JK, Lund U, Mintz B. Total dissolved solids in drinking-water. Background document for development of WHO guidelines fordrinking-water quality. Geneva, World Health Organization, 2003 (WHO/SDE/WSH/03.04/16). 